\title{
Cordonnier Grade 2 Fungal Complication, Candidemia without Severe Sepsis
}

National Cancer Institute

\section{Source}

National Cancer Institute. Cordonnier Grade 2 Fungal Complication, Candidemia without

Severe Sepsis. NCI Thesaurus. Code C138300.

Any candidemia without severe sepsis and without focus. 